\section{Note on a Communication from Mr. A. Lawrence Rotch on the First Registration Balloons in America.}

\author{
By ERIC STUART BRUCE, M.A., Oxon.
}

The Aëronautical Society of Great Britain has lately received a communication from Mr. A. Lawrence Rotch, the Director of the Blue Hill Observatory, on his recent observations with ballon-sondes, at the $\mathrm{St}$. Louis Exhibition, and the following note has been compiled from this communication:-

Mr. Lawrence Rotch states that ajthough the suocessful experiments with kites it Blue Hill led to the extensive use of kites for meteorological observations in variou. countries, ballon-sondes were not used in America until 1904, when Mr. Rotch was cnabled to make a number of ascents at St. Louis, through the co-operation of the management of the Louisiana Purchase Exhibition. A grant of 2,500 dollars was authorised, but only about half this sum was spent for apparatus, travelling, and living expenses.

The type of balloon used was the small indiarubber balloon devised by Dr. Assmann, the Director of the Royal Prussian Aerronautical Observatory, and inade by the Continental Caoutchouc and Gutta Percha Company, of Hanover, Germany. The balloons used, had an initial diameter of approximately six feet when inflated with 100 cubic feet of lyydrogen gas, and, carrying parachute and instruments, exerted a net lift of nearly two pounds. Being closed at the mouth, they rise at an almost uniform rate of speed, expanding meanwhile, and they burst at a height which is dependent on their initial distension.

The Richard recording instruments are attached to a parachute covering the top of the balloon. The parachute moderates the fall of the instruments, which reach the ground comparatively near the point of departure. The fact that all but one of the 23 balloons and instruments dispatched were found and returned shows the efficiency of the arrangements, as well as the excellent topographical situation of St. Louis for this work.
During the month of September, 1904, four ascents were made, all the balloons falling about 50 miles east of $\mathrm{St}$. Louis, within a distance of 15 miles of one another, and at the maximum height of ten and a half miles, a temperature of $-62^{\circ} \mathrm{F}$ was recorded. Another series of ten ascents was made in the latter part of November and the first days of December, mostly after sunset, to aroid the possible effects of insolations. Owing to the stronger air currents at this season, two of these balloons travelled with a mean velocity of more than 100 miles an hour, and all but one fell within the eastern half of a circle, having St. Louis as its centre, and a radius of 280 miles. The exception was a balloon which did not rise above the surface wind. Generally, the drift was away from the areas of low barometric pressure at the ground, thus confirming the theory of the outflow of air above them. An extreme height of almost ten miles was attained, and a temperature of $-76^{\circ} \mathrm{F}$ was found once, somewhat below seven miles.

Mr. Rotch states, that in order to continue these observations during the winter, he carried out, at his own expense, another series of nine ascents during the latter part of January, 1905, and on the days of the International ascents in other countries, in February and March, one of these balloons was lost, but the others fell nearly within the semi-circle described above. Severai of the records are incomplete, owing to the stoppage of the clockwork, and another was obliterated by the finder; but a height excoeding ten miles was indicated, and the extraordinarily low temperature of $-111^{\circ} \mathrm{F}$ was registered at a height of about nine miles, during the prevalence of 2 higi barometric pressure at the ground.

In connection with Mr. Rotch's experiments with ballon-sondes, it is satisfactory that the plan of bringing down the recording instruments to earth by a parachute has been found to be so practical and useful. It will be remembered that at the meeting of this Society on April 15th, 1901, I had the privilege of being the first to propose this plan to the members of this Society, when I experimentally demonstrated my remarks. I repeated this proposal in a paper communicated to the Berlin Congress of the International Aëronautical Commission. Germany, and it is to her credit, has indeed been the first to practically utilize the suggestion, but Great Britain must claim its origination. 
The Presment : This seems a very intercsting paper, and strikes me as containing some extraordinary records.

I think that ends our proceedings.

Mr. E. P. Frost : Ladies and gentlemen. I am sure you will one and all respond to a vote of thanks to our worthy President, Major Baden Powell.

Dr. H. R. MrLl: I have great pleasure in seconding that.

The vote of thanks was carried unanimously, and the proceedings then texminated.

\section{The Wellman Balloon Ex- pedition to the North Pole.}

The attempt of Mr. Wellman to reach the North Pole in a navigable balloon certainly promises to be amongst the most interesting aëronautical events of the current year. This expedition is being financed by Mr. Victor Lawson, the principal owner of the Chicago Record Herald, and a life member of the National Geographical Society, and its cost is atimated at over 250,000 dollars. The scheme has the approbation of the American National Geographical Society, whose Board pro nounced that Mr. Wellman's plans are carefully and thoroughly considered, and give good promise of success.

The Society has appointed Major Henry B. Hersée to be the scientific representa tive of the Nationnl Geographical Society in connection with the expedition, and he will accompany Mr. Wellman on his aërial voyage to the Pole.

To M. Louis Godard has been entrusted the construction of the large airship. Its length is 164.04 feet, its greatest diameter 52.49 feet. It has a surface of 21,098 square feet, and a volume of 224,244 cubic feet. Its highest lifting power is estimated at 16,000 pounds. The weight of the airship, complete with steel car, motors, and machinory is 6,600 pounds, and the weight of the orew, instruments, wireless and other apparatus, gasoline, etc., 9,400 pounds.

The duration of inflation is hoped to be 15 to 20 days.

The airship is provided with two motors, one of 50-horse power, and another of 25-horse power, driving two screws and giving speeds of from 12 to 15 statute miles per hour.
The steel car is 52.5 feet long. There is an enclosed engine-room and cabin for the crew, and an important feature of the scheme is the steel boat, which is suspended below the car. This will serve as a working deck for the manipulation of the guids rope, equilibreur, and retardateur, and for storage of gasoline, and in case of any accident happening to the airship, it will be used by members of the crew in sledging their way back to the headquarters.

The gas bag in its greatest diameter, where the pressure is 45 pounds to the square foot, has three thicknesses of fabric, two of cotton material, and one of silk, with three coatings of rubber. All three are consolidated into one fabric, giving a tensile strength of 575 pounds per square foot. In the next zones, where the pressure is reduced, a lighter silk is used to reduce the weight of the envelope, and in the outer sections, the silk is altogether omitted.

Mr. Wellman is placing much reliance on the retardateur or dragging anchor, a device calculated to offer the maximum of resistance in proportion to its weight, and by this means to drift slowly with an adverse wind. The retardateur consists of a steel cab'e, provided with small projections like hooks or rings, calculated to give resistance equal to the pull of the airship in a wind of about 12 to 15 miles per hour.

The plan of drifting slowly with the tardateur will take the place of firm anchorage. It is estimated that with a wind of 10 to 12 miles an hour, the vessel will remain approximately stationary in the air, perhaps drifting half a mile to a mile per hour. In a wind of 15 miles per hour, the drift should be 5 miles per hour, in 20 miles 8 miles per hour. Should the wind be 30 miles per hour, the driftage should be 18 miles per hour.

In June the apparatus of the expedition was assembled at Tromsoe, in Norway, where the iceship Frithjoi was in readiness. The vessel started for Spitzbergen at the end of the month. Mr. Wellman expected to establish his headquarters at Dane's Island, in Spitzbergen, early in July. A huge shed will be constructed for the airship.

During the latter part of July, trials with the airship will be undertaken. If these preliminary trials are successful, an effort will be made to reach the Pole this year, but if delay is advisable, the attempt will be postponed till next year.

An important feature of the plan will be 